\title{
Draculin, the anticoagulant factor in vampire bat saliva, is a tight-binding, noncompetitive inhibitor of activated factor $X$
}

Citation for published version (APA):

Fernandez, A. Z., Tablante, A., Beguin, S., Hemker, H. C., \& Apitz-Castro, R. (1999). Draculin, the anticoagulant factor in vampire bat saliva, is a tight-binding, noncompetitive inhibitor of activated factor $X$. Biochimica et Biophysica Acta (BBA) - Protein Structure and Molecular Enzymology, 1434(1), 135-142. https://doi.org/10.1016/S0167-4838(99)00160-0

Document status and date:

Published: 14/09/1999

DOI:

10.1016/S0167-4838(99)00160-0

Document Version:

Publisher's PDF, also known as Version of record

\section{Please check the document version of this publication:}

- A submitted manuscript is the version of the article upon submission and before peer-review. There can be important differences between the submitted version and the official published version of record.

People interested in the research are advised to contact the author for the final version of the publication, or visit the DOI to the publisher's website.

- The final author version and the galley proof are versions of the publication after peer review.

- The final published version features the final layout of the paper including the volume, issue and page numbers.

Link to publication

\footnotetext{
General rights rights.

- You may freely distribute the URL identifying the publication in the public portal. please follow below link for the End User Agreement:

www.umlib.nl/taverne-license

Take down policy

If you believe that this document breaches copyright please contact us at:

repository@maastrichtuniversity.nl

providing details and we will investigate your claim.
}

Copyright and moral rights for the publications made accessible in the public portal are retained by the authors and/or other copyright owners and it is a condition of accessing publications that users recognise and abide by the legal requirements associated with these

- Users may download and print one copy of any publication from the public portal for the purpose of private study or research.

- You may not further distribute the material or use it for any profit-making activity or commercial gain

If the publication is distributed under the terms of Article $25 \mathrm{fa}$ of the Dutch Copyright Act, indicated by the "Taverne" license above, 


\title{
Draculin, the anticoagulant factor in vampire bat saliva, is a tight-binding, noncompetitive inhibitor of activated factor $\mathrm{X}$
}

\author{
Ana Z. Fernandez a, Alfonso Tablante a, Suzette Beguín b, H. Coenraad Hemker ${ }^{\text {b }}$, \\ Rafael Apitz-Castro ${ }^{\mathrm{a}, *}$ \\ ${ }^{a}$ Lab. Trombosis Experimental, Centro de Biofisica y Bioquímica, IVIC, Ap. 21827, Caracas 1020A, Venezuela \\ b Department of Biochemistry, University of Maastricht, Maastricht, The Netherlands
}

Received 1 April 1999; received in revised form 1 July 1999; accepted 7 July 1999

\begin{abstract}
The kinetic mechanism of action of Draculin on activated Factor X (FXa) is established. Draculin inhibits activated Factor X within seconds of incubation at near equimolar concentration (2-6 times on molar basis). Fitting the data to the equation for a tight-binding inhibitor gives a value for $K_{\mathrm{i}}\left(K_{\mathrm{d}}\right)=14.8 \pm 1.5 \mathrm{nM}$. The formation of the Draculin-FXa complex can be explained by a two-step mechanism, where for the first, reversible step, $k_{\text {on }}=1.117( \pm 0.169$, S.E.M. $) \times 10^{6} \mathrm{M}^{-1} \mathrm{~s}^{-1}$ and $k_{\text {off }}=15.388( \pm 1.672) \times 10^{-3} \mathrm{~s}^{-1}$, while for the second, irreversible step, which is concentration-independent, $k_{2}=0.072$ $\mathrm{s}^{-1} . K_{\mathrm{d}}$ obtained from $k_{\mathrm{off}} / k_{\mathrm{on}}=13.76 \mathrm{nM}$. Lineweaver-Burk plot shows a noncompetitive behavior. This noncompetitive mode of inhibition of Draculin is supported by the observation that Draculin, at concentrations giving complete inhibition, does not impair binding of $p$-aminobenzamidine to FXa. Moreover, under the same conditions, Draculin induces $<14 \%$ decrease of the fluorescence intensity of the $p$-aminobenzamidine-FXa complex. We conclude that Draculin is a noncompetitive, tight-binding inhibitor of FXa, a characteristic so far unique amongst natural FXa inhibitors. (C) 1999 Elsevier Science B.V. All rights reserved.
\end{abstract}

Keywords: FXa Inhibition; Draculin; Tight-binding inhibitor; Natural anticoagulant; (Vampire bat)

Abbreviations: FXa, activated Factor X; FIXa, activated Factor IX; S.E.M., standard error median; pAB, p-aminobenzamidine; BA, benzamidine; AT-III, Antithrombin III; TFPI, tissue factor pathway inhibitor; TAP, tick anticoagulant peptide; rTAP, recombinant TAP; AcAP, Ancylostoma caninum anticoagulant peptide; SDS-PAGE, sodium dodecyl sulfate-polyacrylamide gel electrophoresis; HRP, horseradish peroxidase; FCA, Freund's complete adjuvant; FIA, Freund's incomplete adjuvant

* Corresponding author. Fax: +58-2-504-1093;

E-mail: rapitz@ivic.ivic.ve

\section{Introduction}

Activation of Factor $\mathrm{X}$ is a common point between the intrinsic and extrinsic pathway of blood coagulation [1]. Activated factor $\mathrm{X}(\mathrm{FXa})$ is the sole enzyme that catalyzes the conversion of prothrombin into thrombin, the key enzyme in the coagulation cascade; therefore inhibitors of this step are of considerable mechanistic and pharmacological interest. In addition to the two known physiological inhibitors of this serine protease, antithrombin III (AT-III) and the tissue factor pathway inhibitor (TFPI), several low molecular mass naturally occur- 
ring polypeptides inhibitors have been described, such as Antistasin, a 119-residue protein isolated from the mexican leech Haementeria officinalis [2,3]; the tick anticoagulant peptide (TAP) [4], a 60-amino acid protein derived from the tick Ornithodoros moubata; Ecotin, a periplasmic protein found in Escherichia coli [5-7]; and the Ancylostoma caninum anticoagulant peptide (AcAP) [8]. These peptides behave as reversible, slow tight-binding inhibitors of FXa, where Antistasin and Ecotin are slowly cleaved by FXa, while TAP is not affected by the protease. Recently, we described a new natural FXa inhibitor, isolated from the saliva of the vampire bat Desmodus rotundus, which was named Draculin. Draculin is a $88.5 \mathrm{kDa}$ glycoprotein which selectively inhibits both FXa and activated factor IX (FIXa) [9]. Furthermore, the anticoagulant activity of Draculin is highly dependent on the proper glycosylation of the polypeptide backbone [10]. The results described in this paper indicate that, in contrast to other natural FXa inhibitors, Draculin behaves as a noncompetitive, tight-binding inhibitor of FXa.

\section{Materials and methods}

\subsection{Materials and reagents}

Hydroxyapatite (Biogel-HTP), acrylamyde and silver-staining reagents were purchased from Bio-Rad Laboratories (Richmond, CA, USA). Benzamidine and $p$-aminobenzamidine dihydrochloride were from Sigma (MO, USA). Coagulation factors were purified by established procedures by Dr. Rob Wagenvoord (Department of Biochemistry, University of Limburg, The Netherlands). FXa concentration was measured by titration with $p$ - $N$ - $p$-guanidobenzoate [11]. The activity of FXa was assayed using the chromogenic substrates S-2222 $\left(K_{\mathrm{m}}=200 \mu \mathrm{M}\right.$, Chromogenix, Sweden $),$ S-2337 $\left(K_{\mathrm{m}}=200 \mu \mathrm{M}\right.$, Kabi Diagnostica, Sweden) and $\mathrm{CH}_{3} \mathrm{OCO}-\mathrm{D}-\mathrm{CHG}$ Gly-Arg-pNA ( $K_{\mathrm{m}}=104 \mu \mathrm{M}$, Pentapharm). Freund's complete adjuvant (FCA) was from Calbiochem (CA, USA) and Freund's incomplete adjuvant (FIA) was from Gibco (OH, USA). EGGstract purification system and Anti-chicken IgY HRP conjugate were supplied by Promega (WI, USA). ECL
Western blotting detection reagents were purchased from Amersham Life Science (UK). All other reagents used were of the highest quality commercially available. For graphics and mathematical approaches, Origin 5.0 Software was used (Microcal Software, MA, USA).

\subsection{Animals}

Vampire bats (Desmodus rotundus) were regularly captured from wild colonies in the region of Choroní (State of Aragua, Venezuela). The bats were kept in captivity, in individual cages of the metabolic type (Acme Metal Products, Chicago, IL, USA), under controlled light and temperature $\left(25^{\circ} \mathrm{C}\right)$. The animals were maintained on bovine blood anticoagulated with $3.8 \%$ sodium citrate at a ratio of $1: 9$. Food was given every $24 \mathrm{~h}$ and water was given ad libitum [12].

\subsection{Saliva collection}

As shown previously [10], the biological activity of Draculin is highly dependent on the appropriate glycosylation of the native protein and seriously affected by the salivation pattern of the animals. Therefore, for the purpose of the present study, saliva collection was done as follows: eight to ten animals were salivated, as previously described [10], at 5-day intervals. Each sample was assayed for protein concentration and FXa inhibitory activity, and kept at $-20^{\circ} \mathrm{C}$ until use. Similar batches were pooled and Draculin purified as already described [10]. Under these conditions, the purified protein obtained had an inhibitory activity of 4.92 nmol FXa inhibited per mg of Draculin.

\subsection{Factor Xa activity}

Factor Xa activity was assayed on specific chromogenic substrates. For the microplate assay of FXa activity, $50 \mu 1$ of each of the hydroxyapatite columneluted fractions was placed in a well with $100 \mu \mathrm{l}$ of buffer A (0.05 M Tris- $\mathrm{HCl}, 0.1 \mathrm{M} \mathrm{NaCl}(\mathrm{pH} 7.35)$ with $0.05 \%$ egg albumin), $3 \mathrm{nM}$ FXa and $20 \mu \mathrm{l}$ of $4 \mathrm{mM} \mathrm{S}-2222$, in a final volume of $180 \mu \mathrm{l}$. After $15 \mathrm{~min}$ incubation at $37^{\circ} \mathrm{C}$ the optical density at $405 \mathrm{~nm}$ was recorded in a microplate reader 
(EL312e Bio-Kinetics reader microplate, Bio-Tek Instruments). Continuous assay of FXa activity was used for quantifying and kinetics studies of the antiXa activity of Draculin. Briefly, 10-13 nM FXa was incubated with Draculin for $1 \mathrm{~min}$ at $37^{\circ} \mathrm{C}$ in a cuvette containing buffer $\mathrm{A}$. The cuvette was placed in a home-made fixed dual-wavelength photometer (Biochemistry and Instrumental Dept., Univ. of Limburg, The Netherlands) for the continuous recording of the reaction at $405 \mathrm{~nm}$. The reaction was started with addition of $35 \mu \mathrm{l}$ of S-2337 (final concentration $=400 \mu \mathrm{M})$. The final volume of the reaction mix was $500 \mu \mathrm{l}$. For kinetic studies, $\mathrm{CH}_{3} \mathrm{OCO}-\mathrm{D}$ CHG-Gly-Arg-pNA, a low- $K_{\mathrm{m}}$ substrate, was used and FXa was in the range of $1-4 \mathrm{nM}$. The reaction conditions were as described above.

\section{5. $p$-Aminobenzamidine binding to $F X a$}

Use of $p$-Aminobenzamidine ( $\mathrm{pAB}$ ) as a fluorescent probe for the active site of serine proteases and its displacement by active site specific ligands (benzamidine, AT III) has been previously reported $[13,14]$. FXa $(1 \mu \mathrm{M})$ and pAB $(75 \mu \mathrm{M})$ were incubated in a microcuvette ( $2 \mathrm{~mm}$ wide, $10 \mathrm{~mm}$ path) with buffer A (final volume $=500 \mu \mathrm{l}$ ). The fluorescence intensity was measured in a spectrofluorophotometer (RF-1501, Shimadzu) with excitation at $336 \mathrm{~nm}$ and emission at $376 \mathrm{~nm}$. Draculin $(7 \mu \mathrm{M})$ was added as described in Fig. 6. Benzamidine (1.13 $\mathrm{mM}$ ) was used as a positive control for $\mathrm{pAB}$ displacement.

\subsection{HPLC of the Draculin-FXa complex}

Draculin and FXa at a ratio of 1:10 were incubated for $10 \mathrm{~min}$ at room temperature. A $25-\mu 1$ sample was loaded on a molecular exclusion column (Protein Pak 300sw, Waters, Millipore, USA). Equilibration of the column and elution of the sample was done with $250 \mathrm{mM}$ phosphate, $\mathrm{pH}$ 6.8. Draculin at the same concentration was run as control. Detection was monitored at $280 \mathrm{~nm}$.

\subsection{Effect of factor Xa on Draculin}

In order to determine if the interaction of Draculin with FXa results in cleavage of the inhibitor, $200 \mathrm{nM}$ FXa and $400 \mathrm{nM}$ Draculin were incubated at room temperature, and aliquots of the reaction mixture were removed at various time points and subjected to Western blotting analysis using anti-Draculin antibodies from egg yolks, obtained as previously described [10]. Detection was done using a chemiluminescent method (Amersham Life Science). Factor Xa and Draculin incubated alone under the same conditions were used as controls.

\subsection{Other methods}

Protein determination was done by the Coomassie blue method [15]. SDS-PAGE was done as described [16]. Gels were stained with Coomassie blue or silver staining. For Western blotting analysis, appropriate methods were used $[17,18]$.

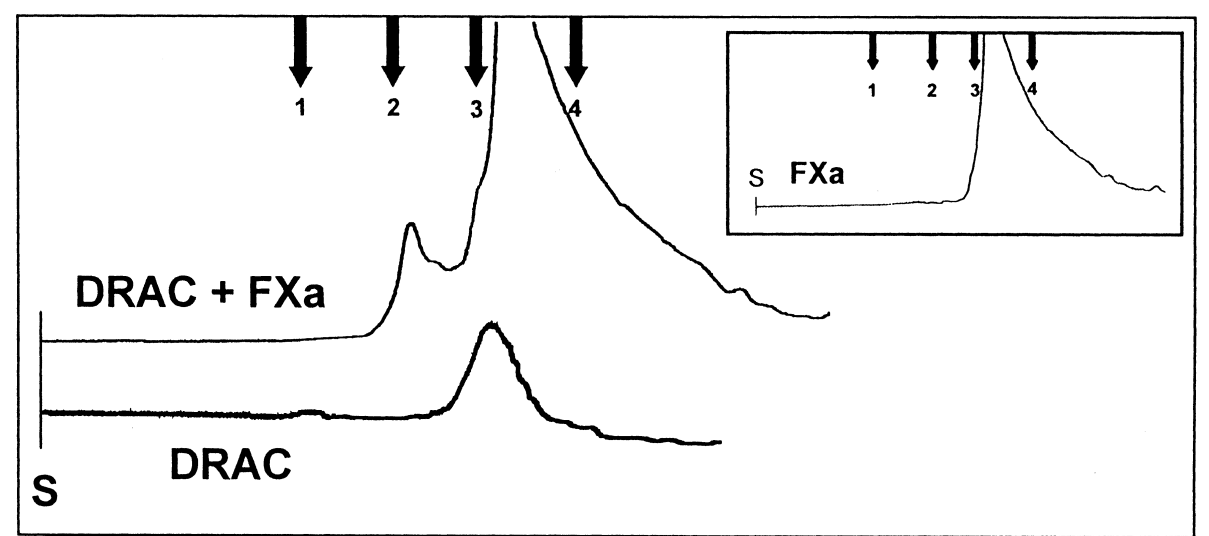

Fig. 1. Molecular exclusion HPLC profile of draculin (DRAC) and a mixture of Draculin and FXa (DRAC+FXa). The arrows indicate elution time of markers: 1, catalase $232 \mathrm{kDa} ; 2$, lactate dehydrogenase $140 \mathrm{kDa}$; 3, phosphorylase $b 94 \mathrm{kDa} ; 4$, albumin 67 $\mathrm{kDa}$. The inset corresponds to the HPLC profile of FXa under the same experimental conditions. 


\section{Results}

\subsection{HPLC of the Draculin-FXa complex}

As shown in Fig. 1, incubation of Draculin with an excess of FXa results in a molecular exclusion pattern in which a new protein peak, with molecular mass in the range of $130-150 \mathrm{kDa}$ is clearly apparent (arrow), suggesting a 1:1 complex between Draculin and FXa, which is not easily dissociated under the experimental conditions used.

\subsection{Effect of factor $\mathrm{Xa}$ on Draculin}

Aliquots from a mixture of Draculin $(400 \mathrm{nM})$ and FXa $(200 \mathrm{nM})$ were taken after 24, 48 and $90 \mathrm{~h}$ of incubation. Western blotting analysis shows no change in the apparent molecular mass of Draculin. Furthermore, degradation products reacting with anti-Draculin antibodies were not observed (not shown). These results indicate that Draculin is not a substrate for FXa.

\subsection{Effect of Draculin on the progress curve for the amidolytic activity of $\mathrm{FXa}$}

Preincubation of FXa with Draculin inhibits the catalytic activity of the enzyme in a dose-dependent manner at concentrations that are comparable to the

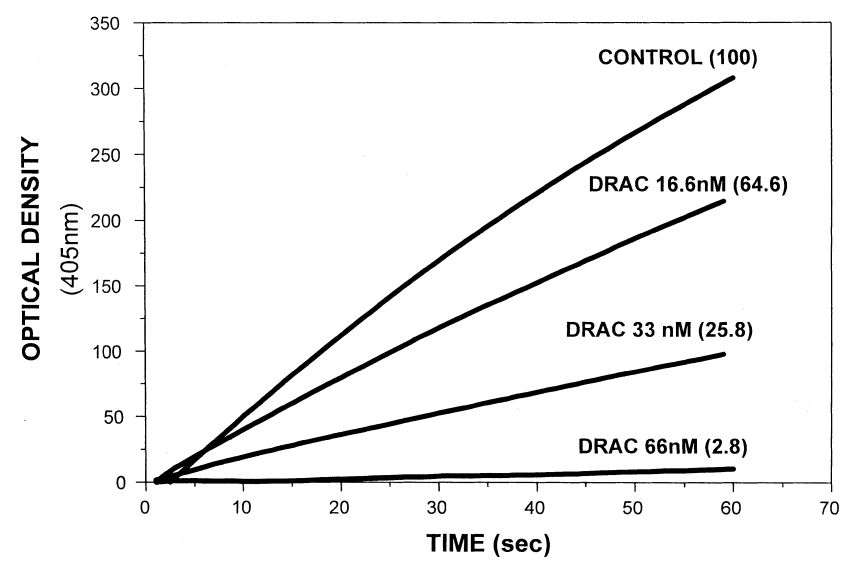

Fig. 2. Progress curves showing the concentration-dependent effect of Draculin on the amidolytic activity of FXa (10 nM). Values in parentheses represent residual activity of FXa (percentage). S-2337 $(400 \mu \mathrm{M})$ was used as substrate. Other conditions as described in Section 2.

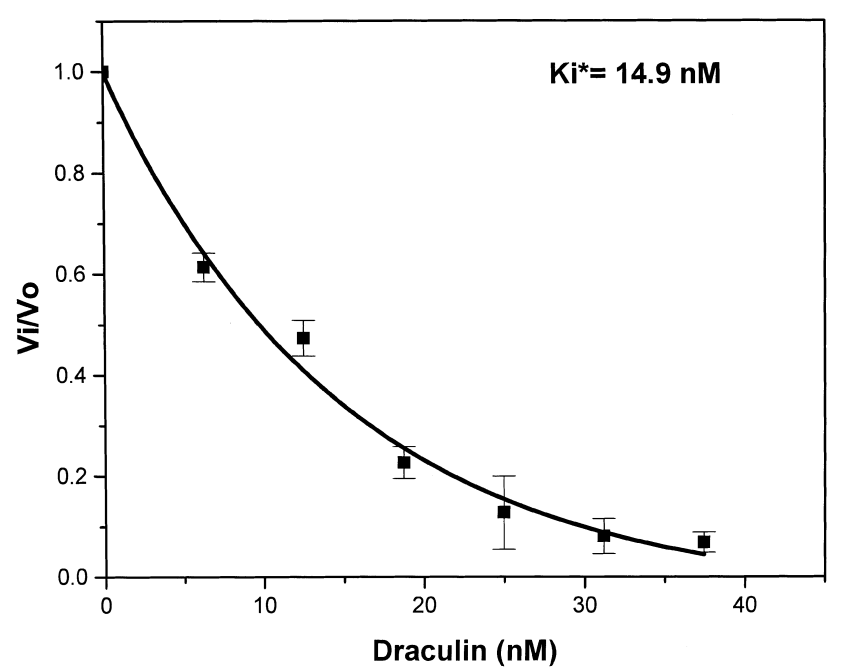

Fig. 3. Determination of the intrinsic $K_{\mathrm{i}}\left(K_{\mathrm{d}}\right)$ for Draculin. The inhibitory activity is expressed as the ratio of the inhibited rate to uninhibited rate (fractional activity). FXa concentration was $10 \mathrm{nM}$. Substrate used: S-2337 $(400 \mu \mathrm{M})$. Experimental data (three determinations) adjusted to Morrison's equation (line) yield a $K_{\mathrm{i}}$ value of $14.8 \pm 1.5 \mathrm{nM}$.

total enzyme concentration (Fig. 2). Increasing the incubation time does not change the degree of inhibition (results not shown). For practical reasons $1 \mathrm{~min}$ incubation time was routinely used. Initial rates were obtained from the linear $(<25 \mathrm{~s})$ part of the progress curve in order to avoid the effect of substrate depletion on the linearity of the progress curve also observed in the control assay. The apparent lag phase shown in the figure at the highest Draculin concentration was not observed in repeated experiments $(n=10)$.

From the progress curves shown in Fig. 2, inhibited $\left(V_{\mathrm{i}}\right)$ and uninhibited $\left(V_{\mathrm{o}}\right)$ initial rates were calculated and then fitted by nonlinear regression to the tight-binding equation [20]:

$\frac{V_{\mathrm{i}}}{V_{\mathrm{o}}}=\frac{1}{2 E_{\mathrm{t}}}\left[\left(E_{\mathrm{t}}-I_{\mathrm{t}}-K_{\mathrm{i}}^{*}\right)+\sqrt{\left(I_{\mathrm{t}}+K_{\mathrm{i}}^{*}-E_{\mathrm{t}}\right)^{2}+4 K_{\mathrm{i}}^{*} E_{\mathrm{t}}}\right]$

where $V_{\mathrm{i}} / V_{\mathrm{o}}$ represents the fractional activity of $\mathrm{FXa}$ (inhibited velocity divided by uninhibited velocity), $E_{\mathrm{t}}$ is the total concentration of enzyme, $I_{\mathrm{t}}$ is inhibitor concentration and $K_{\mathrm{i}}^{*}$ is the dissociation constant (Fig. 3). The value of $K_{\mathrm{i}}\left(K_{\mathrm{d}}\right)$ for the interaction of Draculin and FXa calculated from this equation is $14.8 \pm 1.5 \mathrm{nM}$. 


\subsection{Measurement of rate constants for formation and dissociation of Draculin-FXa complex}

Fig. 4 shows the effect of preincubation of FXa with Draculin (Xa+Drac+S curve) and the effect of Draculin addition after $20 \mathrm{~s}$ of the start of the reaction $(\mathrm{Xa}+\mathrm{S}+\mathrm{Drac}$ curve). Draculin added to FXa in the presence of excess substrate $\left(3 K_{\mathrm{m}}\right)$ very rapidly induces inhibition of the catalytic activity of the enzyme (Fig. 4, Xa+S+Drac curve). The level of the steady state of residual activity is dependent on Draculin concentration as shown in Fig. 2, but is not dependent on the order of addition of Draculin. Prior incubation of factor Xa with Draculin, for longer periods of time, as shown in Fig. 4, does not increase the final degree of inhibition attained. The inhibition progress curves, from experiments presented in Fig. 4 $(\mathrm{Xa}+\mathrm{S}+$ Drac curve), were fit to a single exponential function to obtain the half-time $\left(t_{1 / 2}\right)$ for the inactivation of FXa at different concentrations of Draculin. The values for $k_{\text {obs }}$ were obtained from $k_{\mathrm{obs}}=0.693 / t_{1 / 2}$ [19]. A plot of $k_{\mathrm{obs}}$ vs. Draculin concentration, fitted to a hyperbolic equation (Fig. 5),

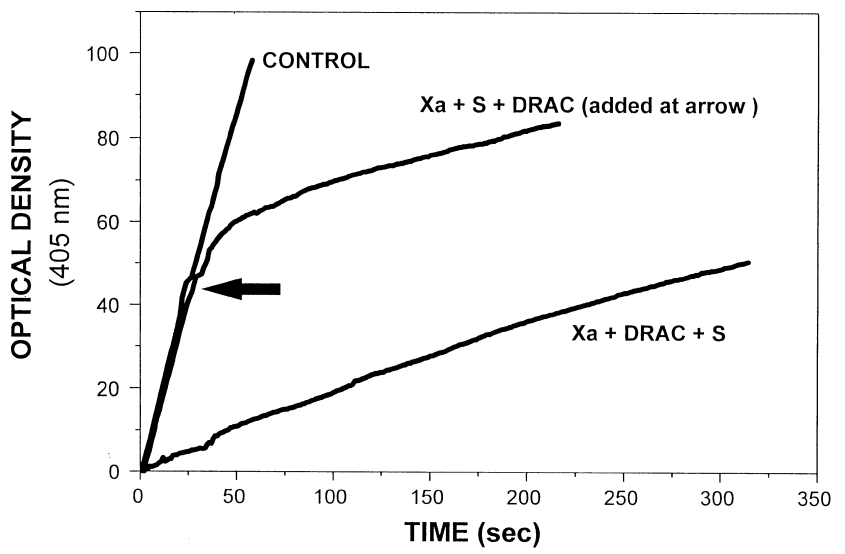

Fig. 4. Time-dependence of the effect of Draculin on the amidolytic activity of FXa. FXa $=1 \mathrm{nM}$; Draculin $=10.4 \mathrm{nM}$; substrate used was $\mathrm{CH}_{3} \mathrm{OCO}-\mathrm{D}-\mathrm{CHG}-\mathrm{Gly}-\mathrm{Arg}-\mathrm{pNA}=400 \mu \mathrm{M}$. Steady-state residual activity is independent of the order of addition and time of incubation of Draculin. Experimental conditions as described in Section 2.

shows a linear, concentration-dependent portion followed, at Draculin concentrations higher than $50 \mathrm{nM}$, by a concentration-independent phase; from the linear part of the plot (concentration-dependent), the

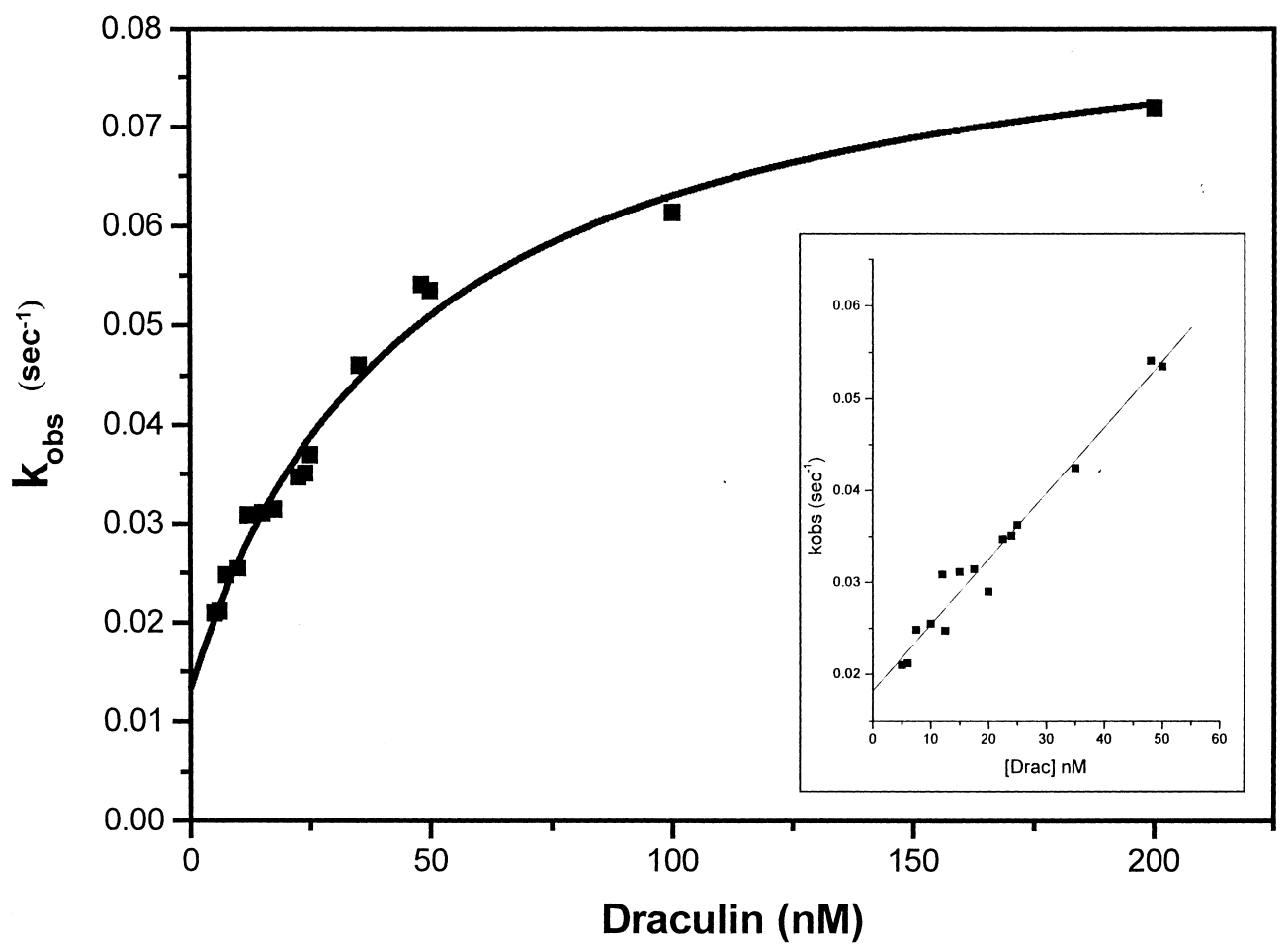

Fig. 5. Dependence of $k_{\mathrm{obs}}$ on Draculin concentration. Values of $k_{\mathrm{obs}}$ were obtained from experiments as shown in Fig. 4, as described in Section 3, at various Draculin concentrations. The association rate constant $k_{\mathrm{on}}$ was calculated from the slope $\left(k_{\mathrm{on}}=k_{\mathrm{obs}} /\right.$ [Draculin] $=1.117 \times 10^{6} \mathrm{M}^{-1} \mathrm{~s}^{-1}$. Value for $k_{\text {off }}$, obtained from the $y$-intercept $=k_{\text {off }}$ is $15.388 \times 10^{-3} \mathrm{~s}^{-1}$. 
relation $k_{\text {obs }}=k_{\text {on }}$ [Draculin] $+k_{\text {off }}$ allows the calculation of $k_{\mathrm{on}}=1.117 \quad( \pm 0.169) \times 10^{6} \quad \mathrm{M}^{-1} \mathrm{~s}^{-1}$ and $k_{\text {off }}=15.388 \quad( \pm 1.672) \times 10^{-3} \mathrm{~s}^{-1} . K_{\mathrm{d}}$, estimated from $k_{\text {off }} / k_{\text {on }}$, equals $13.76 \times 10^{-9} \mathrm{M}$, which is in accordance with the $K_{\mathrm{i}}$ calculated from fitting the fractional activity $\left(V_{\mathrm{i}} / V_{\mathrm{o}}\right)$ data to the tight-binding equation.

Double reciprocal plot of initial rates of conversion of the low- $K_{\mathrm{m}}$ substrate $\mathrm{CH}_{3} \mathrm{OCO}-\mathrm{D}-\mathrm{CHG}-\mathrm{Gly}$ Arg-pNA at different Draculin concentrations yields the typical pattern of noncompetitive inhibition (Fig. $6)$.

\subsection{Effect of Draculin on the binding of the active-site directed probe p-aminobenzamidine to $\mathrm{FXa}$}

The fluorescent molecule $\mathrm{pAB}$ binds to the active site of serine proteases displaying, upon binding, an increase in fluorescence yield [13]. pAB can be displaced, with concomitant decrease of fluorescence, by other compounds that bind to the enzyme active site (i.e., benzamidine, AT-III for FXa) [14]. As shown in Fig. 7A, addition of pAB to FXa alone yields a fast increase in fluorescence and subsequent addition of $\mathrm{BA}$ produces a rapid decrease in fluorescence to almost the baseline level. When pAB is added to the mixture of FXa and Draculin (Fig. 7B), a similar

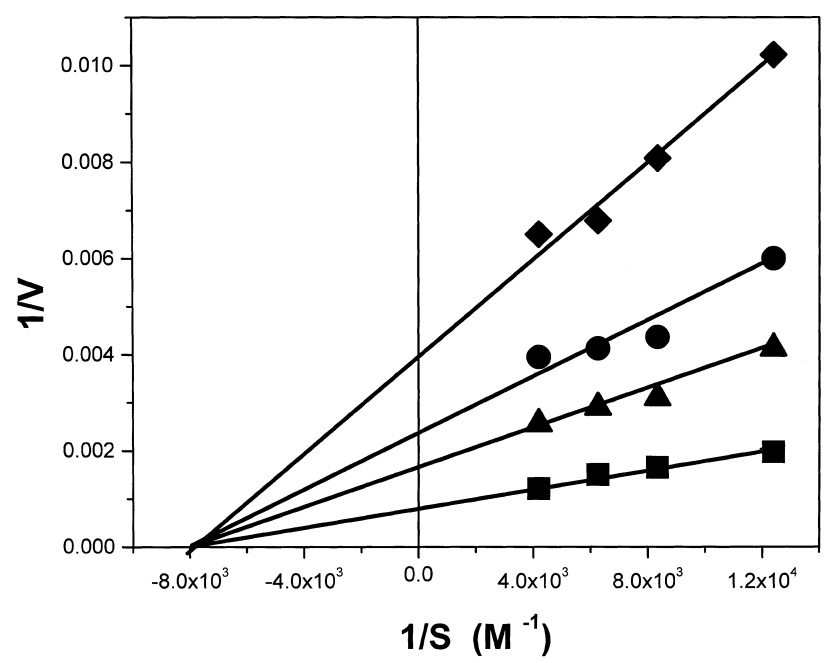

Fig. 6. Double reciprocal plot indicative of the noncompetitive behavior of Draculin. FXa $(4 \mathrm{nM})$; substrate used was $\mathrm{CH}_{3}$ OCO-D-CHG-Gly-Arg-pNA $\left(K_{\mathrm{m}}=104 \mu \mathrm{M}\right)$. (品) Control;

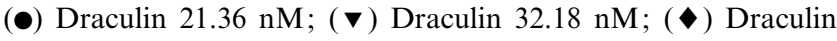
$41.20 \mathrm{nM}$. Solid lines represent the best fit of the data.

increase in fluorescence as in the control (Fig. 7A) is obtained. Furthermore, addition of Draculin to the pAB-FXa complex, at a concentration that completely inhibits FXa activity (Fig. 7C), produces at most a $14 \%$ decrease in the fluorescence yield of the pAB-FXa complex. Increasing time of incubation of

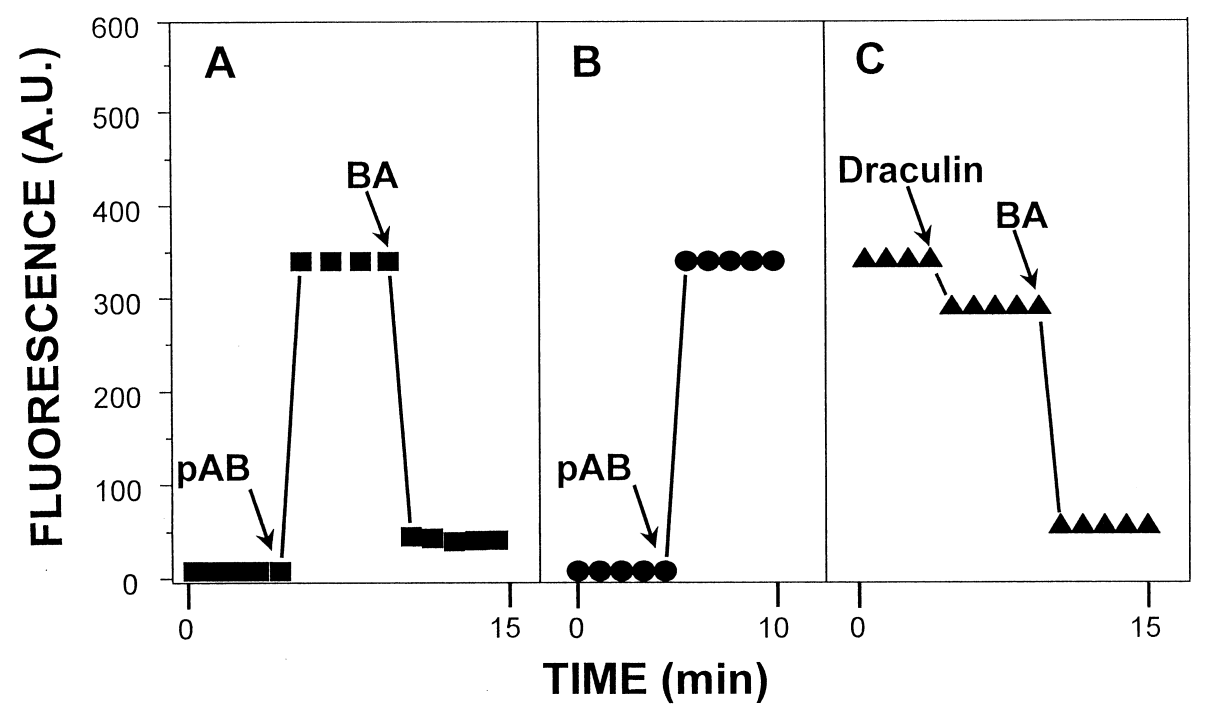

Fig. 7. Effect of Draculin on the binding of the active-site directed probe pAB. (A) pAB (75 $\mu \mathrm{M})$ added to FXa (1 $\mu \mathrm{M})$ alone; addition of benzamidine $(1.13 \mathrm{mM})$ displaces $\mathrm{pAB}$ and decreases fluorescence to basal level. (B) Addition of pAB to FXa preincubated with Draculin $(7 \mu \mathrm{M})$. (C) Addition of Draculin to the pAB-FXa complex decreases by $<14 \%$ the fluorescence yield; addition of benzamidine to the mixture returns the fluorescence to the initial level. 
Table 1

Molecular mass and kinetic parameters of Draculin and other natural anti-FXa polypeptides

\begin{tabular}{llllll}
\hline FXa Inhibitor & Molecular mass $(\mathrm{kDa})$ & $K_{\mathrm{i}}\left(\times 10^{-9} \mathrm{M}\right)\left(K_{\mathrm{d}}\right)$ & $k_{\text {on }} \times 10^{6}\left(\mathrm{M}^{-1} \mathrm{~s}^{-1}\right)$ & $k_{\text {off }}\left(\mathrm{s}^{-1}\right)$ & $15.833 \times 10^{-3}$ \\
\hline Draculin & 88.5 & $13.76-14.80$ & 1.117 & $5.1-5.7 \times 10^{-4}$ & {$[2]$} \\
Antistasin & 15 & $0.31-0.62$ & 1.2 & $0.554 \times 10^{-3}$ & {$[22]$} \\
rTAP & 6.8 & 0.18 & 2.85 & $6.5 \times 10^{-5}$ & {$[6,7]$} \\
Ecotin & 16 & 0.054 & 1.35 & - & {$[8]$} \\
AcAP & 8.7 & 0.323 & - & \\
\hline
\end{tabular}

FXa with Draculin does not produce any further changes. The same figure shows that addition of $\mathrm{BA}$ to this mixture decreases the fluorescence yield as in the absence of Draculin. These results show that Draculin neither impairs binding of $\mathrm{pAB}$ to the enzyme, nor affects its displacement by BA. This implies, in agreement with the noncompetitive kinetic pattern, that Draculin-FXa and DraculinFXa-[S] complexes can be simultaneously formed. The slight decrease in fluorescence yield observed for the binding of pAB to the Draculin-FXa complex might be due to subtle conformational changes in the complex that affect the quantum yield of fluorescence.

\section{Discussion}

Draculin, the anticoagulant glycoprotein isolated from vampire bat (Desmodus rotundus) saliva, is a single-chain polypeptide with molecular mass of $88.5 \mathrm{kDa}$ that selectively inhibits FIXa and FXa [9]. The Lineweaver-Burk pattern, as well as the lack of interference of Draculin with the active-site ligand $p$-aminobenzamidine, clearly indicate that Draculin acts as a noncompetitive inhibitor of FXa. The facts that Draculin establishes a relatively rapid equilibrium with $\mathrm{FXa}$, in a range of similar concentrations of enzyme and inhibitor, and that no lag phase is observed at any of the Draculin concentrations assayed, allows Draculin to be considered within the category of tight-binding inhibitors [21]. The lack of cleavage of Draculin by FXa, even after prolonged periods of time (up to $90 \mathrm{~h}$ ) agrees with the noncompetitive mode of inhibition, a fact that could be potentially advantageous for the vampire bat feeding. We have previously shown that Draculin bound to FXa immobilized on AffiGel is not eluted even after extensive washings of the matrix [9], suggesting that the FXa-Draculin complex can be reasonably considered as irreversible, under the experimental conditions used. These results, in addition to those suggesting that Draculin forms an irreversible complex with FXa, can be explained in part through the formation of an inactive Draculin-FXa complex by a two-step mechanism of the type

$\mathrm{E}+\mathrm{I} \underset{k_{\text {off }}}{\stackrel{k_{\text {on }}}{\rightleftarrows}} \mathrm{EI}^{*} \stackrel{k_{2}}{\longrightarrow} \mathrm{EI}$

where formation of $\mathrm{EI}^{*}$ is concentration-dependent, while transformation of $\mathrm{EI}^{*}$ into EI is concentrationindependent and essentially irreversible. This result is in agreement with our present observation that the Draculin-FXa complex is stable enough to withstand separation through a molecular exclusion column, and supports the assumption of irreversibility for the second step proposed in our kinetic scheme. Since the formation of EI is an essentially irreversible step, the value for $k_{\mathrm{obs}}=0.072 \mathrm{~s}^{-1}$, obtained at the highest Draculin concentration, closely represents $k_{2}$, the rate constant for the concentration independent step.

These facts distinguish Draculin from other known natural anti-Xa polypeptides [2-4,7,8], which behave as competitive, slow, tight-binding inhibitors and, in the case of Ecotin and Antistasin, are reported to be slowly cleaved by the enzyme they inhibit. In Table 1 , we compare the molecular mass and kinetic parameters obtained for the interaction of FXa and Draculin with those published for Antistasin, Ecotin, rTAP and AcAP. Although $k_{\text {on }}$ is in the same range of values reported for the other inhibitors, the fact that $k_{\text {off }}$ is one to two orders of magnitude faster makes Draculin a weaker inhibitor $\left(K_{\mathrm{d}}\right.$ in the $\mathrm{nM}$ range). The noncompetitive behavior of Draculin may be a plausible explanation for its dual, nonin- 
terfering inhibitory action on both FIXa and FXa [9], and perhaps a biological advantage to the blood-feeding need of the vampire bat. Structure-activity relationship studies, under way in our laboratory, should help to identify portion(s) of the molecule relevant to its interaction with activated factors IX and X, which may lead to the design of new anticoagulant compounds with distinctive inhibitory mechanisms.

\section{Acknowledgements}

The authors are deeply indebted to Dr. Magaly Bracamonte de Zambrano and Mr. Javier Campos (Rabies Div, Inst. Invest. Vet, FONAIAP, Maracay, State of Aragua, Venezuela) for their invaluable collaboration in the capture of wild vampire bats. This work was supported in part by the International Scientific Cooperation Program of the European Community-Andean Pact Countries, Contract CII*CT920062. The critical reading of the draft manuscript by Professors Mahendra K. Jain (Delaware), Michael H. Gelb (Seattle) and Ariel Escobar (IVIC) is greatly appreciated.

\section{References}

[1] H.C. Hemker, S. Beguin, Thromb. Haemost. 74 (1995) 134 138.

[2] C. Dunwiddie, N.A. Thornberry, H.G. Bull, M. Sardana, P.A. Friedman, J.W. Jacobs, E. Simpson, J. Biol. Chem. 264 (1989) 16694-16699.
[3] N. Ohta, M. Brush, J.W. Jacobs, Thromb. Haemost. 72 (1994) 825-830.

[4] L. Waxman, D.E. Smith, K.E. Arcuri, G.P. Vlasuk, Science 248 (1990) 593-595.

[5] C.H. Chung, H.E. Ives, S. Almeda, A.L. Goldberg, J. Biol. Chem. 258 (1982) 11032-11038.

[6] M.E. McGrath, W.M. Hines, J.A. Sakanari, R.J. Fletterick, C.S. Craik, J. Biol. Chem. 266 (1991) 6620-6625.

[7] J.L. Seymour, R.N. Linquidst, M.S. Dennis, B. Moffat, D. Yansura, D. Reilly, M.E. Wessinger, R.A. Lazarus, Biochemistry 33 (1994) 3949-3958.

[8] M. Cappello, G.P. Vlasuk, P.W. Bergum, S. Huang, P.J. Hotez, Proc. Natl. Acad. Sci. USA 92 (1995) 6152-6156.

[9] R. Apitz-Castro, S. Beguin, A. Tablante, F. Bartoli, J.C. Holt, H.C. Hemker, Thromb. Haemost. 73 (1995) 94-100.

[10] A.Z. Fernandez, A. Tablante, F. Bartoli, S. Beguin, H.C. Hemker, R. Apitz-Castro, Biochim. Biophys. Acta 1425 (1998) 291-299.

[11] G.W. Jameson, D.V. Roberts, R.W. Adams, W.S.A. Kyle, D.T. Elmore, Biochem. J. 131 (1973) 107-117.

[12] J.M. Dickson, D.G. Green, Lab. Anim. 4 (1970) 37-44.

[13] S.A. Evans, S.T. Olson, J.D. Shore, J. Biol. Chem. 257 (1982) 3014-3017.

[14] D.M. Monroe, G.B. Sherril, H.R. Roberts, Anal. Biochem. 172 (1988) 427-435.

[15] M.M. Bradford, Anal. Biochem. 72 (1976) 248-258.

[16] H. Schagger, G. von Jagow, Anal. Biochem. 166 (1987) 368379.

[17] U.K. Laemmli, Nature 227 (1980) 680-685.

[18] H. Towbin, T. Staehelin, J. Gordon, Proc. Natl. Acad. Sci. USA 76 (1979) 4350.

[19] S. Cha, R.P. Agarwall, R.E. Parks, Biochem. Pharmacol. 24 (1975) 2187-2197.

[20] J.W. Williams, J.F. Morrison, Methods Enzymol. 63 (1979) 437-467.

[21] J.F. Morrison, Trends Biochem. Sci. 6 (1982) 102-105.

[22] S.P. Jordan, L. Waxman, D.E. Smith, G.P. Vlasuk, Biochemistry 29 (1990) 11095-11100. 